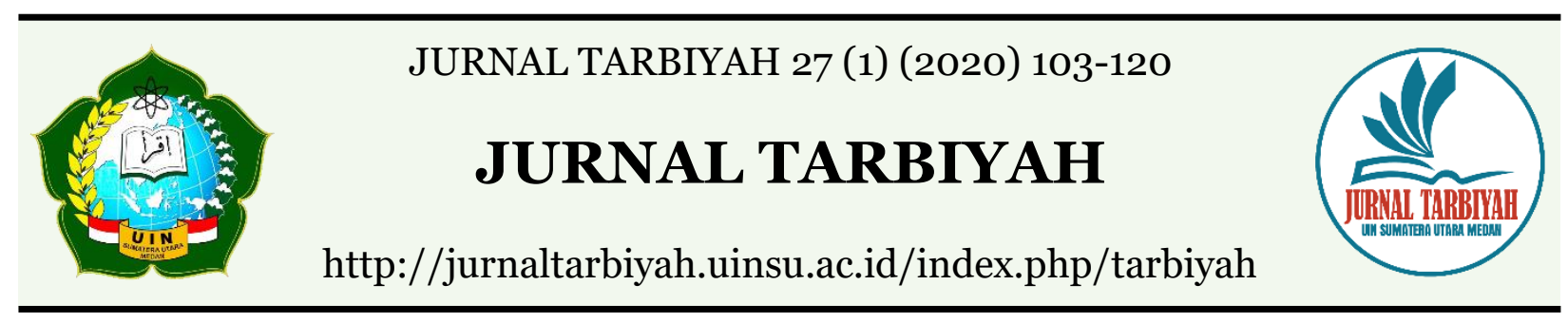

\title{
THE CONCEPT OF CHILD IN THE PERSPECTIVE OF THE QUR'AN (THEMATIC INTERPRETATION STUDY)
}

\author{
Abd Halim Nasution \\ Universitas Islam Negeri Sumatera Utara, Medan, Indonesia \\ Email :halimnasution17@gmail.com
}

DOI : 10.30829/tar.v27i1.685

Accepted: January 17th, 2020. Approved: June 25th, 2020. Published: June 3oth, 2020

\begin{abstract}
The revival of Islamic religion has formed a new atmosphere for the condition or fate of the children of Arabs. Islam forbids the killing of children through the prohibition of Allah, among others, contained in QS. Al-Isra/17: 31. Besides prohibits killing children, featuring the provisions of Islamic law that shows how important attention to and even how to look after children with a loving since before and after birth. The Qur'anic view of children globally formulated in the principle:"The children do not cause problems and suffering of parents and also vice versa" In the Qur'an, Allah says "Do not be a mother suffering difficulties because of his son and father do not have to suffer because of his son, and likewise heir duty." Qur'an has serious concern about the child. This is evident from the various terms used in the Qur'an to show the meaning of the child as źurriyah, ibn, walad, sabiy, usbah, gulam, thifl, nasl, rabaib, and ad'iya '. As a review of the limitation, this study will analyze the concept of child in the perspective of the Qur'an (interpretation of thematic studies).
\end{abstract}

Key words: child, concept, the perspective of the Qur'an 


\section{INTRODUCTION}

In the study of Islamic history, before the arrival of Islam in Arab regions, children were not treated well. In some Arab tribes, there was a habit of killing child by burying them alive. The behavior of people at that time was similar to animals that eat their own offspring (Fathiyah, 1979:11).

The revival of Islam established a new atmosphere for children in Arab regions. Islam banned the killing of children such as in the Qur'an, Al-Isra, 17:31. In addition, legal provisions in Islam also mentions the importance of taking care a chid before and after the child birth. The Qur'anic view of children globally can be formulated in the principle: "Children are not the cause of hardship and misery of parents and vice versa". In the Qur'an (Al-Baqarah: 233), Allah says “...No mother should be harmed through her child, and no father through his child. And upon the [father's] heir is [a duty] like that [of the father]..." (Fathiyah, 1979:11).

The Qur'an as a guide (Huda) (A-Baqarah/2:2, 97 and 185; Al-Maidah/ 5:46) can always guide humans in organizing their lives and as the source of knowledge (Al-An'am/ 6:38, An-Nahl/ 16:89). The Qur'an informs what humans can do to organize their lives through concepts, amśal-amśal, and stories of both individuals and groups as teachings, comparison, guidance and warning.

This study aims to see how the term and status of children in the Qur'an and why the Qur'an expresses different terms about children. The depth understanding of the concept of children will have an impact on the implementation of education to be more communicative so that it can create a pleasant atmosphere for children/students, and it is expected to improve the quality of educational outcomes. As the limitation of the study, this study will analyze the concept of children in the perspective of the Qur'an (thematic interpretation study).

\section{LITERATURE REVIEW}

Family is the smallest unit in society consisting of a husband and wife, father and child, mother and child, or blood relatives in a straight line up or down to the third degree (Law Number 23: 2002). A child is defined as "manusia yang masih kecil" or young human (Kamus Besar Bahasa Indonesia, 1999:35).

The definition of children also includes the time the child exists; this is to avoid the definition of children in their relation to parents and the definition of children once they become parents. In the Qur'an, children are often refered to by the word "walad" in the 
form of "jamakawlad" which means that a child is born from a mother's womb, male of female, small or big, single of plural. The word "al-walad" is used to describe a lineage, so the word "al-walid" and "al-walidah" are interpreted as biological father and mother. In contrast to the word "ibn" which does not necessarily indicate a lineage and the word "ab" does not necessarily mean a biological father. (Sihab, XV 2004: 614) The Qur'an also uses the term "thifl" (Q.S. al-Nur (24):31 and 59; al-Hajj (22): 5; al-Mukmin (40): 67) and ghulam(Q.S. Ali Imran (3): 40; Yusuf (12): 19; al-Hijr (15) 53; al-Kahfi (18): 80; Marya, (19) 7,8 and 20; al-Shaffat (37): 101 and al-Dzariyat (51): 28)

In the applicable legislation in Indonesia, such as in Law Number 4 of 1979 concerning Child Welfare Article 1 paragraph 2 states that "A child is a person who has not reached the age of 21 (twenty one) years and has not married yet"; and specifically (legal formal) in Article 1 number 1 of law number 23 of 2002 concerning Child Protection, and article 1 number 5 of law number 21 of 2007 concerning Eradication of Criminal Acts of Trafficking in Persons, namely; "A child is someone who is not yet 18 (eighteen) years old, including a child in the womb".

Studies and researches on children in the Qur'an have been carried out and specifically in relation to education. The related study includes Child Education in the Qur'an by Sulaiman Saat, lecturer at the Faculty of Tarbiyah and Teacher Training at the Faculty of Tarbiyah Universitas Islam Negeri Alaudin Makassar in 2010 in the journal of Lentera Pendidikan. Another related study is such as the perspective by Abdul Hafis and Hasni Noor, in Journal Muallimuna, Universitas Islam Kalimantan in 2016, which is about theories of children's education and verses related to children's education.

Such studies can be used as a comparison for this study, but they are not used as concerete references because different studies are assumed to have different patterns and colors.

\section{METHODOLOGY}

\section{The Research Design}

This study is conducted by using Content Analysis because this study wants to collect Qur'anic verses related to the concept of children, and with the Maudu'I study which means the tafsir methodology to find answer in the Qur'an about a problem by gathering all related verses, and the analysis is done through relevant sciences to produce the whole concept of the Qur'an about the problem (Al-Farmawy, 1976 :41-42) 


\section{The source of data}

The primer data for this study is the Qur'an and the secondary data for this study are books related to the issue discussed. This study follows library research, in the sense that all data are gathere $d$ from written materials related to the topic discussed. The second source is books related to Tafsir that can represent this study such as;

1. Tafsir Jami' al-Bayan 'an Ta'wil ayyu Alquran (Tafsir At-Tabariy), a popular tafsir written by an expert of tafsir Tarikh Islam, Al Imam Abu Ja'far Muhammad bin Jarir bin Yazid bin Katsir bin Ghalib At-Tabariy who lived in 224-310 H.

2. Tafsir Mafatih al-Gaib (Al-Kabir) written by al-Imam Fakhruddin ar Raziy, This tafsir is one of the most comprehensive interpretations of birra'yi which is the most comprehensive one because it explains the entire Qur'anic verse. Abu Hayyan asserted that Fakhruddin ar-Razi collected and explained many things at length in this interpretation so that (as if) it is no longer needed interpretation.

3. Tafsir Al-Mishbah written by Prof DR. M. Quraish Shihab, indeed he is not the only expert of the Qur'an in Indonesia, but his ability to translate and convey the messages of the Qur'an in the context of present and post modern times makes him better known and superior to other Qur'anic experts.

In completing and further refining the analysis and discussion, this study uses; $A l-$ Mu’jam al-Mufahras li alfaz al-Qur'an al-Karim; Al- Mufradat fi al-Gharib Alfazh Alquran written by Abu Qasim al-Husayn Ibn Muhammad al-Raghib al-Asfahani; kamus Lisan al-'Arab written by Ibnu Manzural-Ansari; At-Ta'arif, written by Muhammad Abdurra'uf Al-Munawwy, Maqayis al-Lugah, Mu'jam al-Wasith, Al-Misbah al-Munir, Tajul 'Arus, and ect.

\section{The Instrument of data generation}

In this study, the instrument used in data generation is Data Coding, the term "child" is searched in the Qur'an and when it is interpreted in the context of a verse related to the concept of a child, its content is analyzed because not all of these words have anything to do with the concept of children.

\section{Technique of Collecting Data}

The data are collected by following the instructions in books entitled Mu'jam alMufahrasy li alfazi al-Qur'an al-Karim and Barnamij Nas al-Qur'an al-Karim written by Umran Salim and also with the assistance of computers with Digital Qur'an proram.. 
The meaning of word related to a child is searched in books entitled Lisan al-'Arab, Taj al-'Arus, Mishbah al-Munir, mu’jam and etc.

\section{The Analysis of Data}

The research procedures:

1. Identifying verses that contain words refering to child in the Qur'an.

2. Classifying the verses based on chronological events

3. Displaying the interpretations from mufasir about the verses that contain the word "child".

4. Understanding and analyzing the interpretations from mufasir by comparing the viewpoints of mufasir with the theories of child in the perspective of experts in education.

5. Drawing conclusions from the rest of the section and at the same time answering the main questions presented above. At this point, we address all issues related to the concept of children in the Qur'anic perspective.

\section{FINDINGS}

\section{Different Terms of "Child" In The Qur'an}

The term "child" is explicitly metioned in the Qur'an 238 times in 50 chapters with the same and different topics, and expressed in 10 terms.

1. Walad, in its single and plural form is found 71 times in 29 chapters.

2. Ibn, in its single and plural forms is found 119 times in 41 chapters.

3. Zurriyyat, in its single and plural forms is found 31 times in 19 chapters.

4. At-Thifl, in its single and plural forms is found 4 times.

5. Ghulam, in its single form, mutsanna and plural form is found 13 times in 8 chapters.

6. Sabiyy, only in its single form is found 2 times in 1 chapter.

7. An-Nasl, in its single form is found 2 times in 2 chapters.

8. Rabaib, in its plural form is found 1 time in 1 chapter, namely An-Nisa'.

9. Ad'iya, in its plural form is found 2 times in 1 chapter, namely Al-Ahzab.

10. Al-'Usbah, in its single form is found 4 times in 3 chapters.

11. The word "child" is stated implicitly such as in the Qur'an Al-'Araf/7: 189, 190 (salihan) and in the Qur'an Mayam/19:5 (waliya). 


\section{The Status of Child in the Qur'an}

a. Child as a trust

Trust is something that is entrusted (given) to others, (Kamus Besar Bahasa Indonesia, 1999:30), a trust given to a person in relation to the preservation of property (Dahlan, Abdul Aziz et.al, 1996: 104). A child is a trust from Allah the almightly to be cared by parents, as in the Qur'an Allah says in At-Tahrim/66:6 "O you who have believed, protect yourselves and your families from a Fire whose fuel is people and stones, over which are [appointe] angels, hars and severe; they do not disobey Allah in what He commands them but do what they are commanded." This verse is a guide and command from Allah to Islamic believers so that they can guide themselves and educate their family (Al-Alusy, tt xxi: 101), and also to be responsible to escape from the torment of hell, believers should learn and teach taqwa to Allah SWT, with their knowledge to submit to Allah SWT and also to guide and teach their family to submit to Allah SWT (At-Thabari, tt xxiii: 492).

A child as a trust, globally in the perspective of the Qur'an is formulated in the principle "Children are not the cause of hardship and misery of parents and vice versa". In the Qur'an chapter Al-Baqarah/2:233 Allah states “...No mother should be harmed through her child, and no father through his child. And upon the [father's] heir is [a duty] like that [of the father]...”. Parental responsibility and care for the child are the responsibility of physical and psychological development of a child.

\section{b. A child as an enemy}

In the Qur'an, chapter At Taghabun/64:14, Allah states "O you who have believed, indeed, among your wives and your children are enemies to you, so beware of them. But if you pardon and overlook and forgive - then indeed, Allah is Forgiving and Merciful.” This verse states that among your wives and children, there are enemies who prevent you from the path of Allah, prevent you from obeying Allah, then beware of them not accepting what they command in the matter of obedience to Allah SWT.

In the tafsir of At-Tabary, it is stated that this verse descended on people who wanted to convert to Islam and emigrated, but their wives and children prevented them from committing the pilgrimage (At-Tabary, tt xxii:415). Quraish Sihab states that children are enemies because they can turn their parents away from religion, or demand something beyond their parents' ability that might let their parents to break the law of Allah (Sihab, xiv 2004:278). 
In the Tafsir Al-Kabir, Al-Razi (tt xiv: 368 ) it is stated that as an enemy because a child is a test from to human's allegiance to Allah, and a child who instructs his parent to do illegal activities such as stealing something. At-Tabataba'i (tt iii: 353) it is explained that a child is called as an enemy in the aspect of faith, turning away the parents from good deeds such as infaq, emigrating from disbelieving countries, using unlawful ways and etc.

\section{c. Child as temptation or trial}

The term "walad" in the Qur'an is an independent individual who becomes the second generation of hereditary links. A child is not an investment and capital to improve life ranks, not as a sedative and soulmate. A child (walad) has the role of being a trial for his parents, can be an enemy, can be a barrier to remember Allah, can act as a partner in disobedience to Allah, and the child (walad) cannot help his parents from the punishment of Allah SWT. Allah the almighty mentions that the property and children (auladuhum) of the disbelievers cannot reject Allah's punishment from themsevels (Ali-Imran, 3:10), therefore Allah warns believers not to allow their interest to property and children attracts them because their possessions and children might torture them in their life and hereafter if they are in a state of infidelity (QS. At-Taubah/9:55)

Both verses above state that wealth and children are temptation or trial from Allah SWT, and Allah has a greater reward namely heaven with all the pleasures in it. "And know that your properties and your children are but a trial and that Allah has with Him a great reward" (Al-Anfal, 28). Furthermore, At-Thabari (tt xxii: 486) states that wealth and children of the munafiqs have attracted the attention of the Prophet Muhammad Saw, indeed wealth and children can torture them in the world and the hereafter if they are in a state of infidelity.

In At-Tabataba'i (tt xix: 170), it is stated that temptation or trial is something with which the person is tempted and tested. Wealth and children are temptation because both are decorations in this world to which human lust is easily attracted by this, so human is tested by this trial and for those who prioritize wealth and children than the afterlife and obedience to Allah, so wealth and children are factors who can neglect human. Wealth and children are pleasures in the world for human, games and jokes, wealth is used for human's decoration and mutual pride.s

Allah compares wealth and children to rain which fall on plants that amaze farmers, and when the plants become dry, the plants turn yellow and destroyed. 


\section{A child (ibn)}

a. A child (ibn) as zinah (jewelry)

Unlike a child (walad), a child (ibn) functions as zinah (jewelry) in this world. Zinah, as described by Ragib, is essentially something that does not bring disgrace to someone both in this life and hereafter (Ragib, tt: 223). In regards to zinah (jewelry), in the Qur'an, Ali-Imran/3:14, Allah SWT mentions that "Beautified for people is the love of that which they desire - of women and sons, heaped-up sums of gold and silver, fine branded horses, and cattle and tittled land. That is the enjoyment of worldly life, but Allah has with Him the best return.”

In At-Tabataba'i (tt iii: 353), it is stated that unbelievers assume that wealth and children will be able to protect them, Allah SWT dismiss this view in which wealth and children will not help them from the punishment from Allah SWT. This assumption makes them deviate the rules from Allah SWT by loving their favorite treasures and children and focus on them compared to more important thing, namely the hereafter. Allah the almighty states in the Qur'an, Ali-Imran verse 14 that "That is the enjoyment of worldly life, but Allah has with Him the best return”. Therefore, the joy of wealth and children as part of human life must be used as a means to achieve happiness in the hereafter.

Allah SWT has made human nature to like children and the pleasures in the world, but it is up to the human himself, to the point where he can use children and property to submit to Allah SWT, and it is wrong for humans to make wealth and children as their goals of living. In the Qur'an, al-Kahfi/ 16:46 "Wealth and children are [but] adornment of the worldly life. But the enduring good deeds are better to your Lord for reward and better for [one's] hope", and in al-Qashash/28:60 "And whatever thing you [people] have been given - it is [only for] the enjoyment of worldly life and its adornment. And what is with Allah is better and more lasting; so will you not use reason?”

Caring toward children, both male and female, is human's nature, as well as liking to women (wives) because the aim is to continue the generation, although Allah the almighty mentions and reminds people that the jewelry of this world is to test human beings among those who best of his deeds.

Allah SWT reminds human that good deeds are eternal. Accoding to Shihab (viii 2004:70), this means that the wealth and children that you are proud of and become the world adornments are impermanent, while good deeds are eternal and better for Allah SWT. Treasure and children are trials, the pleasures in this world. The world is only for a 
moment, jewelry whose purpose besides to make the hearth feel happy and proud for those who have it.

From the explanation above, it can be concluded that the child (ibn) might prevent human from obeying Allah SWT at the time when human does not consider it as the pleasure of the world.

b. Child (ibn) as a motivator for taqwa

A child (ibn) as a result of the care and education of parents or others can be a stimulus for their parents in carrying out obedience to Allah, as revealed in the story of the prophet Ibraim AS. (QS. As-Shaffat/37:102-106 "And when he reached with him [the age of] exertion, he said, "O my son, indeed I have seen in a dream that I [must] sacrifice you, so see what you think." He said, O my father, do as you are commanded. You will find me, if Allah wills, of the steadfast." (102). "Indeed, this was the clear trial" (106).

The verse above shows that the prophet Ismail as a child (ibn) responded to the prophet Ibrahim As's request as parent to carry out obedience to Allah SWT at the sacrifaction of the prophet Ismail AS. The prophet Ismail As gave a positive response by motivating his parents that Insha Allah he (Ismail As) will be able to carry out obedience to Allah SWT together with his parents by carrying out the slaughtering. A child (ibn) as a result of the care and education of their parents can function as motivators and partners in carrying out obedience to Allah SWT.

c. Child (zurriyat) as light

Allah SW mentions in the Qur'an, Al-Furqan/25:74 "And those who say, Our Lord, grant us from among our wives and offspring comfort to our eyes and make us an example for the righteous." Ibn Abbas mentions the meaning of "qurratu a'yun" is to obey Allah the almighty so that our eyes are calm because of them in this world and hereafter (AtThabary, tt xix:318). It is pleasant and soothing views of the world in matters relating to religious life rather than its relation to the life in this world (Ar-Razy, xi tt:456). Then, Ibn Abbas states that lilmuttaqina imama means to make us as leaders to follow and become example for people after us (At-Thabary, tt xix: 319). The existence of generation (zurriyat) as the light of two eyes of course when the child becomes zurriyatanthoyibah, (QS. AliImran/3:38), zurriyatan saliha, (QS. ar-Ra'du/13:23), zurriyat who performs shalat, (QS. Ibrahim/14:37,40), zurriyat who is submissive and obedient to Allah, (QS. Al-Baqarah/2:118) not zurriyat who is zalim.(QS. Al-Baqarah/2:124; As-Shaffat/37:113)

The description above shows that the child (zurriyat) can function as a two-eye light that soothes the view, becomes a soulmate and brings inner piece. In order for the 
child to reach the level of martabat qurrata 'ayun, then every parent should not leave the child at the time of his death in zurriyatandhiafa, weak orphans without inheritance and starvation (Ar-Razy, v tt: 32)

\section{d. Child as gulam}

A child described in the term gulam is mentioned in the Qur'an in the singular form, and two/mutsanna dan jamak. In 14 times, and five times of this is started with the word basyira (happy), (QS. Yusuf/12:19; 15:53; 19:7; 37:101; 51:28), and in the form of jamakgilman to indicate teenagers/ young people as if the pears are stored which gives joy and pleasure to the inhabitants of heaven (QS. At-Thur/5223-24). A child (gulam) can encourage and become pleasing thing for his parents, Sihab (xii 2004: 63) mentions that the condition of the prophet Ismail AS (gulamun halim) at the time of the sacrifaction is certainly no doubt, that long before the even had instill in the hearts and minds of their children about the oneness of Allah and His beautiful attributes and how they should behave towards Allah. The prophet Ismail As' attitude can be seen in the Qur'an as an education for the prophet Ibrahim AS.

E. The context of the term "child"

1. The term Walad

Of many terms, the term walad can be classified into several topics, namely:

a. A child as an heir or a descendant that is the second person in the family environment, a newborn child who is still breastfed, the child as an heir is called a walad. A child as a descendant and a second person in the family environment is a mandatory and a responsibility that must be cared and raised by parents. This can be understood from the Qur'an Al-Baqarah/2:233 "Mothers may breastfeed their children two complete years for whoever wishes to complete the nursing [period]. Upon the father is the mothers' provision and their clothing according to what is acceptable. No person is charged with more than his capacity. No mother should be harmed through her child, and no father through his child. And upon the [father's] heir is [a duty] like that [of the father]. And if they both desire weaning through mutual consent from both of them and consultation, there is no blame upon either of them. And if you wish to have your children nursed by a substitute, there is no blame upon you as long as you give payment according to what is acceptable. And fear Allah and know that Allah is Seeing of what you do." In regards to give a living, in the Qur'an, it is stated that "children do not become the cause of adversity and misery of parents and vice versa". 
b. A child is human being who is still small and breastfed, young human being who is weak as female and elderly male (QS. An-Nisa/4:75) seen as weak, effortless (QS. AnNisa/4:98,127)

c. A child as an independent individual is compared to wealth, as the perception of infidels that their property and children can help them from the punishment of Allah. (QS.Ali Imran/3:10, Saba'/34:35). A child as an independent individual is similar to wealth which cannot help their parents on the Day of Judgment and vice versa. (QS.Luqman/31:33, al- Mujadilah/58:17)

d. A child as a second person and as individual can become a temptation or trial, enemy and pleasure in this world (QS. Al-Anfal/8:28, at-Tagabun/64:14,15, Nuh/71:21) as a means of doing wrong (QS. Al-Isra'/17:64), to proud of yourself (QS. Al-Hadid/57:20); preventing people from remembering and obeying Allah (QS. Al-Munafiqun/63:9)

2. The term $I b n$

The analysis of the term "ibn" is focused on two aspects, namely a child as an independent individual and as an individual whose potential should be developed:

a. In the Qur'an, Ali Imran/3:61, the invitation of the prophet Muhammad saw to the polytheists and infidels to change by involving children. Children (bana) brought by Rasulullah are their grandchildren, namely Hasan and Husein (Ar-Razy, iv tt: 421, alZamakhsyari, i tt:83;dan Shihab, viii 2004:112)

In the Qur'an, Hud/11:78 the prophet Luth AS said these are my daughters. They could be his biological daughters or the domestic daughters. The two verses above indicate the term ibn (abnaukum dan banati) can be used for children and adult. Thus, the use of the term $i b n$ is used for a child as a biological heir and also other children.

b. The prophet Yaqub gives advice to their children by saying yabanaiyya (QS. Yusuf/12:67); the teachings given by Rasulullah Muhammad Saw to his wives and daughters calling them as abna...... namely (QS. Al-Ahzab/33:59); the advice from the prophet Ibrahim As and Yaqub As to their children (QS. Al-Baqarah/2:132). Luqman addressed his children when teaching them is bunayya(QS. Luqman/31:13,17); the prophet Ibrahim As calls the prophet Ismail As when the prophet Ibrahim As described his dream. (QS.as-Shaffat/37:102).

The verses above generally use the term "ibn" with the context of the conversations shows the existence of the process of education, learning guidance. Why is the term used by the messenger of Allah swt with the term baniyya dan bunaiyya, why Allah uses banatika in conveying orders to Rasulullah Saw to teach his daughters and other 
daughters of the same believers? The word of Allah SWT in the Qur'an AlAhzab/33:59. "O Prophet, tell your wives and your daughters and the women of the believers to bring down over themselves [part] of their outer garments. That is more suitable that they will be known and not be abused. And ever is Allah Forgiving and Merciful."

Ragib al-Ashfihani (tt:60; Al-Munawiy,1410 H: 30) mentions that the word "ibn"

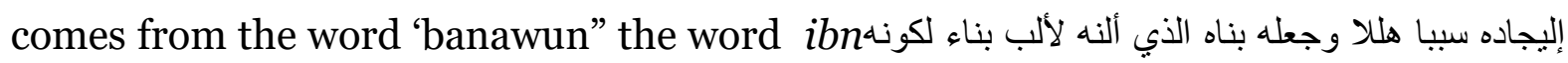
a child is called as ibn, because he is a building for his parents, because Allah the almighty made his parents as the cause of a child, the Ragib mentions that the activities carried out by someone for others such as educating him, visiting/guiding him, helping him a lot, or carrying out his business, then that person was called " hua abnahu" so the term "ibn" in various verses show the emphasis of meaning on education, coaching/mentoring and providing assistance for children's growth and development.

3. The term Zurriyat

The term Zurriyat in the Qur'an indicates that:

a. A child who is still little and young, weak (zurriyatun dhu'afa) (QS.alBaqarah/2:266); a child/grandchild to be protected by Allah swt from the devils (QS. Ali Imran/ 3:36).

b. A good and pious child. The prophet Zakariyya prayed to Allah Swt to be given a good child (zurriyatan thoyyibah) (QS.Ali Imran/3:38); the prophet Ibrahim As hopes that his descendants will become imam (leader) (QS. Al-Baqarah/2:124); Some descendants of the prophet Ibrahim placed near the Baitullah so that they pray (QS. Ibrahim/14:37); there are descendant of the prophet Nuh and the prophet Ibrahim who become prophets, can become guidance and some of them are fasiq (QS. AlHadid/57:26); submissive generation (QS. Al-Baqarah/2:128); generation who performs shalat (QS.Ibrahim/14:40); zurriyat as qurratu a'yun(QS. AlFurqan/25:74); the generation of the propthet Ishaq becomes muhsin, and zalimu linafsih (QS as-Shaffat/ 37:113); the generation who follows his parents who are the believers (QS.at-Thur/52:21); zurriyat who is pious accompanying them in the heaven (QS. Ar-Ra'd/13:23)

The verses above with the term zurriyat, generally emphasizes on psychological aspects of children with the nature of: (1). Good children (zurriyatan thoyyibah), (2). Descendants who can become priests, (3). Descendants who perform shalat, (4). 
Descendants who get guidance, (5) Descendants who are submissive to Allah (Islam) (6). Descendants with a light of two eyes (qurrata a'yun), (7). The generations of muhsin (good). However, Allah swt states that some of the descendants (zurriyat) are zalimun linafsih and fasiq.

c. Anak keturunan (zurriyat) sebagai cikal bakal manusia yang masih berada pada tulang belakang orang tuanya diambil persaksiannya bahwa Allah Swt sebagai rabnya, "And [mention] when your Lord took from the children of Adam - from their loins their descendants and made them testify of themselves, [saying to them], "Am I not your Lord?" They said, "Yes, we have testified." [This] - lest you should say on the day of Resurrection, "Indeed, we were of this unaware", (QS. Al-'Araf/ 7:172)

From the explanation above, it can be understood that the term zurriyat for a child indicates thata a child has the potential to be developed, the potential refers to: (1). The recognition of Allah as his God (QS/7:72), (2). The potential to submit and obey Allah, the potential to be acknowledged and obedient to Allah, this is illustrated by the meaning of qurrata 'ayun and is a follow-up for those who are pious (Ar-Razy, xi tt:46). To be able to be a part of the muttaqin of course must be with knowledge and good deeds.

Even though every child has the potential to submit to Allah the almightly, it turns out that not all have the actual potential. This has been warned by Allah in answering the prayer of th e prophet Ibrahim PBUH, that among the descendants of the prophet Ibrahim PBUH there are those who become imams and there are those who do wrong (QS.al-Baqarah/2:124), as well as the descendants (zurriyat) of the prophet Ishaq PBUH. There are muhsin and zalimu linafsih (QS. As-Shaffat/37:113)

4. Term Thifl

The term thifl in the Qur'an indicates that:

a. The development of a human from turab, nutufah, alaqah, mudgah dan thifl "O People, if you should be in doubt about the Ressurection, then [consider that] indeed We created you from dust, then from a sperm-drop, then from a clinging clot, and then from a lump of flesh, formed and unformed - that We may show you. And We settle in the wombs whom We will for a specified term, then We bring you out as a child, and then [We develop you] that you may reach your [time of] maturity. And among you is he who is taken in [early] death, and among you is he who is returned to the most decrepit [old] age so that he knows, after [once having] knowledge, nothing. And you 
see the earth barren, but when We send down upon it rain, it quivers and swells and grows [something] of every beautiful kind (QS. Al-Hajj/22:5)

"It is He who created you from dust, then from a sperm-drop, then from a clinging clot; then He brings you out as a child; then [He develops you] that you reach your [time of] maturity, then [further] that you become elders. And among you is he who is taken in death before [that], so that you reach a specified term; and perhaps you will use reason (Al-Ghafir/ 40:67)

b. The biological development of a child until he reaches ihtilam (adult) (QS. AnNurr/24:59), psychological development of a child (thifl) who does not understand the intimate parts of body. "And tell the believing women to reduce [some] of their vision and guard their private parts and not expose their adornment except that which [necessarily] appears thereof and to wrap [a portin of] their headcovers over their chests and not expose their adornment except to their husbands, their fathers, their husbands' fathers, their sons, their husbands' sons, their brothers, their brothers' sons, their sisters' son, their women, that which their right hands possess, or those male attendants having no physical desire, or children who are not yet aware of the private aspects of women. And let them not stamp their feet to make known what they conceal of their adornment. And turn to Allah in repentance, all of you, O believers, that you might succeed. (QS. an-Nur/24:31).

Thifl is a newborn child whose growth still needs the help of his parents until he reaches baligh (Ibn Zakariya, iii 1979: 322). Az-Zabidy (tt:7263-7264) states that the term thifl is for children up to mumayyiz, the term thifl is used for children up to they reach mumayyiz phase, and after that phase, the term thifl is not used anymore. (Abu al-'Abbas, ii tt:374)

The term thifl in the paragraph above describes the biological growth of children up to the age of ihtilam/adult and psychological growth of children up to the level of not understanding female aurat (intimate parts), cannot distinguish the aurat yet.

5. The term Gulaam

The term Gulaam is used for humans and others, in the form of Gulman masdar which means to have a strong lust for a relationship between husband and wife (Ibn Manzhur, xii tt:439). Of the 13 times, the term gulaam in its single form, two and plural, as good news from Allah the almighty to the prophet Ibraim, Ishaq and Zakaria AS by giving them gulam. In understanding the Qur'an, as-Shaffaat/37:101, At-Tabary the term 
gulamin halim is a child who is very patient after he grew up because in childhood, children are still cradled not mentioned as Gulaamin halim. (At-Tabari,xxi tt:72)

In the Qur'an, as-Shaffaat/37:102, it is mentioned that when the child (the prophet Ismail AS) reached the age of being able to work with the prophet Ibrahim, the prophet Ibrahim described his dream and the prophet Ismail answered by saying that do what is entrusted to you, Insya Allah, I will be among those who are patient. This age is thirteen years old, and at that time the prophet Ismail AS was already a gulamun halim, a child who has the perfect level of patience (Ar-Razi, xiii tt:138)

The verse above shows that at the phase of ghulam (early adolescence), children already have self-identity, have a strong personality as a result of education in childhood. 6. Assobiyy

The term As-Sabiyy (infant), is mentioned in the Qur'an in two verses namely in chapter 19:12 and 29. The first verse shows that the prophet Yahya AS is given wisdom in infancy and the second verse shows the prophet Isa AS was still in the cradle.(Ibn Zakariya, iii 1979:322). In the Qur'an, Maryam/19:12 it is mentioned that when the prophet Yahya AS was still in sabiyy, he was given ability to understand the book of Allah SWT in childhood before adulthood, "[Allah] said, "O John, take the Scripture with determination." And We gave him judgement [while yet] a boy" (QS. Maryam/19:12) the word "hikmah" in this verse refers to the understanding of Taurat, religious or prophet because Allah SWT appointed the propthet Yahya AS and the prophet Isa AS to be the prophets when they were children (Ar-Razi, $\mathrm{x}$ tt: 276; Az-Zamakhsyari, iv tt:68). From this verse, we can understand that religious learning should be started from the time when the child is still in the cradle, such as gentle treatment, exemplifying religious values through daily behavior and attitudes and others.

7. Nasl;

The term Nasl is mentioned in the Qur'an, as-Sajadah/32:8. Then, He made his descendants from the essence, nasl means can be understood as a child and a descendant as the plural form of ansal and nasilah. Ansala; fall, is mentioned fall and grow and develop. Annasl; which is separated from something, is called a child because he was born from his parent (Ibn Manzur, xx tt :660).

8. Rabaib

"Prohibited to you [for marriage] are your mothers, your daughters, your sisters, your father's sisters, your mother's sister, your brother's daughters, your sister's daughters, your [milk] mothers who nursed you, your sisters through nursing, your wives' 
mothers, and your step-dauhters under your guardianship [born] of your wives unto whom you have gone in. But if you have not gone in unto them, there is no sin upon you. And [also prohibited are] the wives of your sons who are from your [own] loins, and that you take [in marriage] two sisters simultaneously, except for what has already occurred. Indeed, Allah is ever Forgiving and Merciful" (QS. An-Nisa/4:23)

Rabibatu ar-rajul; the child of his wife with a previous husband (stepchild) Ibn Abbas (v tt:337) states that the meaning behind rabaib daughter of his wife, not biological children, it is called as rabaib because his stepdaughter is within the scope of his care.(ArRazi, tt:609)

\section{9. 'Usbah}

A group of people between 10 to 40, this Ushbah is a close family on the part of the father because they are with him (Ibn Manzur, xiii tt: 515), the word of Allah in the Qur'an, Yusuf/12:14, "They said, "If a wolf should eat him while we are a [strong] clan, indeed, we would be losers."

\section{Ad'iya}

The word of Allah in the Qur'an, Al-Ahzab/33:4, "Allah has not made for a man two hearts in his interior. And He has not made your wives whom you declare unlawful your mothers. And he has not made your adopted sons your [true] sons. That is [merely] your saying by your mouths, but Allah says the truth, and He guides to the [right] way."

The verse above expressly states that adopted children are not the same as children (ibn) as descendants of married couples, the statement of someone "you are my father" or "you are my child" does not change the position of a child or father.

\section{CONCLUSION}

\section{A. Conclusion}

Based on the findings of the study, it can be concluded that:

1. The differences in stating the term "child" in the Qur'an indicates the importance of different treatments in dealing with children in their growing and developing age, and the importance of the status, role and function of a child for parents.

2. The term "child" in the Qur'an is informed through the characters and traits attached to the child. For instance a growing child (thifl), growing from a physically weak and 
gentle, developing interest in the opposite sex until entering adolescence (ihtilam), this phase is called gulam.

3. The term gulam indicates early adolescence, at this time personal identity can be seen such as sincerity, ability to know and understand, patient and gentle.

4. The term zurriyat indicates that each child has the potential to submit to and obey to Allah. Thus, there should be an effort to develop it, without developing there might be children who become fasiq and zalimun linafsih in their adulthood.

5. The term ibn indicates that children are the result of development from their parents and others. Thus, ability to build skills is needed to educate and develp the potential of submission to Allah SWT.

6. A child, although there is a lineage with the parents, he or she does not belong to their parents because children are independent individuals. Children cannot benefit their parents on the hereafter because what is beneficial is the virtue that has been done to their children.

\section{REFERENCES}

Abd al-Baqy, Fuad Muhammad, Al-Mu’jam al-Mufahras li Alfaz al-Qur'an al- Karim, Maktabah Dahlan: Indonesia, tt.

Abdul Mustakim, "Kedudukan dan Hak-hak Anak dalam Perspektif al-Qur'an," Jurnal Musawa, (vol.4 No. 2, Juli-2006)

Abu al-Abbas, 'Ali al-Fayyumi, Ahmad bin Muhammad, al-Mishbah al-Munir fi Garib Alquran Al-Karim.

Al-Alusy, Sihabuddin Mahmud bin Abdullah al-Husain, Ruh al-Ma'ani fi Tafsir al- Qur'an al-Karim wa as-Saba' al-Masani,http://www.altafsir.com,

Al-Asfihani, al-Ragib, Mufradat al-Faz al-Quran al-Karim, ed. Nadim Mar'asyili: Dar alFikri, Beirut, tt.

Al-Farmawy, Abd al-Hay, Al-Bidayah fi at-Tafsir al-Maudhu’i, Mesir, al-Maktabah alJumhuriyah, 1976.

Al-Munawiy, Abdurrauf, Muhammad, At_Ta'aarif, ed, Muhammad Ridhwan aDayyah, Dar al-Fikr, Beirut, Cet $1410 \mathrm{H}$.

Al-Razi, Abu 'Abdullah Muhammad bin 'Umar bin hasan bin Husain, Tafsir alKabir/mafatih al-Gaib, http://www.altafsir.com.

At-Tabari, Muhammad bin Jarir bin Yazid bin Katsir bin Galib al-Amaliyy, Jami' alBayan fi Ta'wil al-Qur'an, Muassasah ar-Risalah, tt . 
At-Tabtaba’i, Tafsir Al-Mizan, http://www.shamela.ws/,

Az-Zabidiy, Muhammad bin Muhammad bin Abd ar-Razzaq al-Husaini, Tajul 'Arus min Jawahir al-Qamus, http://www.alwarraq.com.

Az-Zamakhsyari, Abu al-Qasim Amri bin Ahmad,al-Kassyaf, http://www.altafsir.com

Dahlan, Abdul Aziz, et.al, Ensiklopedi Hukum Islam, Jakarta: Ikhtiar baru Vanhove, 1996 Fat-hiyah Hasan Sulaiman, Tarbiyatu Al Thifli Baina al Madhi wa Al Hadhir, Mesir, Dar Al Syuruq, 1399 H/1979 M.

Ibn Manzur, Muhammad bin Mukram, lisan al-'Arab, Dar Sadir, Beirut. tt.

Ibn Zakariya, Abu al-Husain Ahmad bin Faris, Mu'jam Maqayyis al-Lugah, Daar al-Fikr, Beirut, 1979.

Ibrahim Musthafa, al-Mu'jam al-Wasith, Dar an-Nasyr: Daar ad-Da'wah, tt Instruksi Presiden Nomor 1 Tahun 1991 tentang Kompilasi Hukum Islam

Saifullah, “Problematika Anak dan Solusinya (Pendekatan Sadduzzara)," Jurnal Mimbar Hukum, Jakarta, Al-Hikmah dan DITBINBAPERA Islam No. 42 Tahun X 1999.

Shihab, M. Quraish, Tafsir Al-Misbah:Pesan, Kesan, dan Keserasian al-Qur'an, Jakarta, Lentera Hati, 2004

Sya'rawi, Muhammad Mutawalli, Tafsir as-Sya'rawi,http://adel-ebooks.mam9.com

Tim Penyusun Kamus Pusat Pembinaan Dan Pengembangan Bahasa, Kamus Besar Bahasa Indonesia, cet-10; Jakarta: Balai Pustaka, 1999

Undang-undang Nomor 1 Tahun 1974, tentang Perkawinan

Undang-undang Nomor 23 Tahun 2002, tentang Perlindungan Anak. 